\title{
THE DEVELOPMENT OF STRATEGY OF INDONESIAN NAVAL REPAIRMENT AND MAINTENANCE FACILITY (FASHARKAN) TO SUPPORT THE READINESS OF BATTLESHIPS IN FIRST FLEET COMMAND BY USING TOWS METHOD (CASE STUDY FASHARKAN JAKARTA)
}

\author{
Kuncoro', Budisantoso W. ${ }^{2}$, Okol Sri Suharyo ${ }^{3}$, As'ad Aris ${ }^{4}$ \\ 1,3,4 Indonesian Naval Technology College, Bumimoro-Morokrembangan, Surabaya 60187, Indonesia \\ 2Industrial Engineering Department, Institut Teknologi Sepuluh Nopember, Surabaya, Indonesia
}

\begin{abstract}
Repair and Maintenance facility Jakarta is supporting facility component of Indonesian Naval Fleet which has duties to maintain and repair the ships that location is very strategics in Naval Base I. This is as KRI berth and technical condition preparation before doing the operation. The purpose of this research is to determine alternative strategy and roadmap for developing Fasharkan Jakarta with using TOWS analysis (Treaths Opportunities Weaknesses Strength) and ISM (Interpretative Structural Modeling). According to result of TOWS matrix analysis, SO strategy is consisting of eight strategic, four strategic for ST, nine strategic for WO, and four strategic for WT. Based on Weighting by using EFAS and IFAS matrix, WO strategy is as the choosen strategy, as the result WO strategy is become the first alternative. According to the elements clarification results for WO strategy, it gets five levels hierarchy. In this hyrarcy structure can be known that WO8 and WO9 sub strategies are in the level five position, then WO7 sub strategy in the level four strategy. Besides, in the level III is consist of WO5, in the level II is sub strategy WO1, WO3, WO6 and in the level I there are WO2 and WO4 sub strategies.
\end{abstract}

Keywords: Repair and Maintenance Facility Jakarta, Developing Strategic, TOWS and ISM.

\section{INTRODUCTION}

In the Global Marine Technology Trends 2030 report, the power map of the countries in the world will experience drastic changes in 2030.Asia will pass North America and Europe in terms of global power, which are grouped into types of potential technology in three major sectors, namely shipping, shipping and utilization. sea space. In this projection, Indonesia is seen as one of the countries that will have an increasing power (emerging power) in 2030. However, a note to note is that Indonesia needs to increase its maritime power, so that it is able to manage the potential and threats that may arise in their territorial waters. (Phillips, 2008).

The TNI Commander has set 11 (eleven) priority programs for 2018 in accordance with government policy commitments and the importance of synchronizing the development of the TNI force title with national development. This policy is in line with the national maritime policy through the concept of Indonesia as a World Maritime Axis which was conveyed by President Joko Widodo at the 9th East Asia Summit (EAS), 13 November 2014. Where the national development agenda will be focused on five main pillars, namely: First, rebuilding Indonesia's maritime culture;
Second, protecting marine resources and creating seafood sovereignty by placing fishermen on the main pillar; Third, give priority to infrastructure development and maritime connectivity by building sea tolls, deep seaports, logistics, the shipping industry, and maritime tourism; Fourth, Implementing maritime diplomacy, through proposals to increase cooperation in the maritime sector and efforts to deal with sources of conflict, such as illegal fishing, violation of sovereignty, territorial disputes, piracy and marine pollution with an emphasis that the sea must unite various nations and countries and not separate; and Fifth, building maritime power as a form of responsibility for maintaining shipping safety and maritime security.

In carrying out its main duties, Fasharkan Jakarta has the function of providing maintenance and repair facilities for $\mathrm{KRI}$ who will carry out repairs, maintaining the level of readiness of Harkan's facilities and infrastructure in the Fasharkan environment so that they are able to accept the burden of maintenance and repair tasks for elements of the Navy, plan maintenance and repair activities at the depot level, medium and emergency repair of Fleet I 
Commando equipment and workshop equipment based on the plan and program of Disharkap Koarmada I in providing maintenance support for $\mathrm{KRI}$.

Fasharkan Jakarta is a type A Fasharkan, according to the Fasharkan type "A" language, which has the ability to repair and maintain all types of KRI up to the depot level. However, the current condition of Fasharkan Jakarta's ability is still limited in terms of implementing the repair and maintenance of $\mathrm{KRI}$, because there are several things that still need to be improved and changes in the future, including the condition of existing human resources (HR) both in terms of quality and quantity is still not fulfilled, limited human resources who have certification, so that they have not been able to carry out KRI repairs up to the depot level. The current docking capability of Fasharkan Jakarta is only capable of docking up to a capacity of 600 tons, Fasharkan Jakarta currently does not have a Graving Dock (pool dock) with a capacity of 5000 tons. Besides that, the workshop facilities, safety equipment and supporting transportation equipment are old and still manual, so they are still behind the sea lift technology.

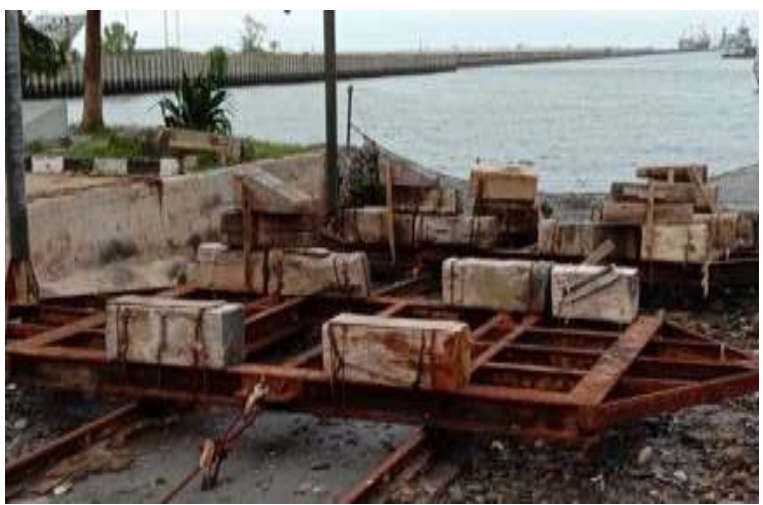

Figure 1 . Slipway 50 Tons Fasharkan Jakarta.

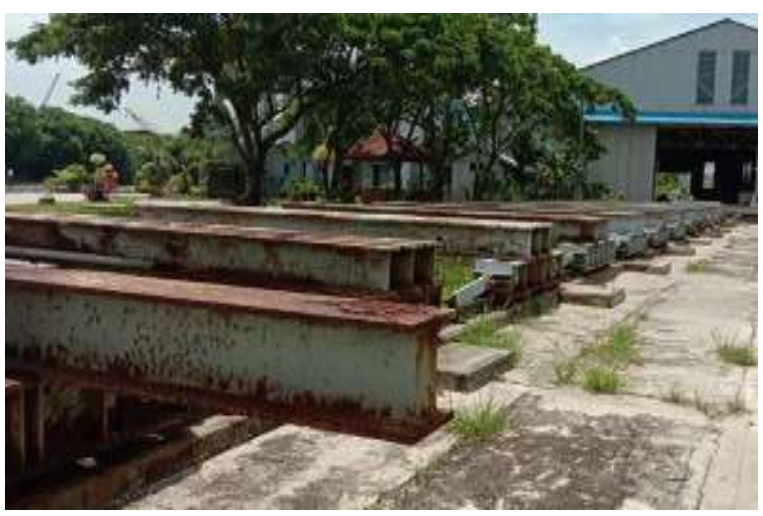

Figure 2 . Slipway 750 Tons Fasharkan Jakarta.

Fasharkan Jakarta as a supporting component for base facilities is in a strategic location, where the location is the Fleet I base / homebass, which is the berth for the completed $\mathrm{KRI} / \mathrm{KAL}$ as well as a place to prepare technical conditions for ships that will carry out operations, in connection with The operational demands and main duties of the $\mathrm{KRI}$, increasing the ability of Fasharkan Jakarta to be very appropriate to get attention in an effort to increase the ability of Fasharkan class A standards. Regarding the ability and position of Fasharkan who is in Koarmada I, the author is interested in conducting in-depth research at Fasharkan Jakarta by taking the title "Fasharkan TNI AL Development Strategy to Support the Readiness of KRI Koarmada I Using the TOWS-ISM Method (Case Study of Fasharkan Jakarta), which had never been studied before. By analyzing external and external factors, a matrix showing strengths and weaknesses as well as opportunities and threats will be obtained, so that an analysis can be carried out to determine the right strategy in the development of Fasharkan Jakarta.

This research uses the integration of the analysis methods Threaths Opportunity Weakness Strength (TOWS) and Interpretative Structural Modeling (ISM) in formulating the development strategy of Fasharkan Jakarta. TOWS stands for Threats (threats), Opportunities (opportunities), Weaknesses (weaknesses) and Strengths (strengths). TOWS analysis is an analysis of internal and external resource management to be formulated into a strategic action (Wheelen \& Hunger, 1995). TOWS analysis is a modification of the SWOT analysis, with a different perspective on looking at the problem. This evaluation puts forward the assessment of external factors and the possibilities that will occur in the future (opportunities and threats) rather than internal conditions and current conditions (strengths and weaknesses) as a consideration for decision making and policy making (Ichwanda, 2015). Internal and external factors are referred to as strategic factors, and are summarized in the TOWS analysis. Strengths and weaknesses are factors in the system that allow and hinder the organization from achieving its goals. Opportunities and threats are considered as external factors that facilitate and limit organizations in achieving their respective goals (Wasike, Magothe, Kahi, \& and Peters, 2010). The logic used in the TOWS analysis is the same as the SWOT logic, namely by separating the criteria into 4 factors of Threats, Opportunities, Weaknesses and Strengths. After that, an assessment of each 
factor is carried out by maximizing the supporting factors for the benefits (strengths and opportunities) and / or minimizing the factors that cause losses (weaknesses and threats) (Ayub, Razzaq, Aslam, \& Iftekhar, 2013). There are several TOWS analysis strategies that are commonly applied in this study, including SO (Strength Opportunity), WO (Weakness Opportunity), ST (Strength Threats), WT (Weakness Threats). ISM is an analytical method that can be used in interactively solving problems to develop several types of structures, including structure effects (eg supporting or worsening), priority structures (eg more important than or will be studied first).

\section{MATERIAL AND METHODS \\ 2.1 Strategic Management Concept}

Strategic management is a managerial action in making decisions in determining the direction of performance in the long term of an organization which includes observing the influential environment, formulating or planning a strategy, implementing evaluation and implementing the strategy itself ( $\mathrm{J}$. David Hunger, 2003). Etymologically, the strategy comes from Greek which is derived from the derivative of the word strategos, in the Athenian era of democracy which meant "military commander". However, from the perspective of terminology, experts have different understandings of the meaning of strategy, but basically have a similar meaning or meaning, namely a plan to achieve goals efficiently and effectively (Syahtaria, 2019).

According to (Istiqomah, 2017) Strategic management can be defined as the art and science of formulating, implementing, and evaluating cross-functional decisions that enable organizations to achieve their goals. This definition implies that strategic management focuses on integrating management, marketing, finance / accounting, production / operations, scriptwriting and development, and information systems to achieve organizational success. The term strategic management in this text is used synonymously with the term strategic planning.

(Hunger \& Wheelen, 2010) Strategic management is a set of managerial decisions and actions that determine the long-term performance of an organization. This includes environmental scanning, strategy formulation, strategy implementation, and evaluation and control. The strategic formulation emphasizes monitoring and evaluation of external opportunities and threats taking into account the strengths and weaknesses of the company. Development is done by adjusting the characteristics of the object. (Bandono, 2017)

\subsubsection{Human Resource Management Concept}

Human Resource Management (HR) has become more important in strategic management, particularly as a result of its role in providing a competitive advantage to boost competitiveness. According to Wright, et al, HR practices cannot form the basis for sustainable competitive advantage but human resources have a greater potential to be a source of sustainable competitive advantage, human resources mean skilled employees in the organization. With the rapid development of this global economy, both practitioners and academics have identified the importance of the Human factor for the success of an organization. The main objective of human resource management is to use the salaried staff in an organization effectively and benefit the organization. So that the organization can achieve its goals and continue its function.

Competency certification is the process of providing a systematic and objective certification of one's competence or expertise through competency tests based on work competency standards, both nationally and internationally. The competency measure is based on the attitudes, knowledge, skills and expertise possessed by that person. Meanwhile, the competency test aims as a tool to obtain authentic valid evidence as a reference for whether the competency test participant is competent or not on the competency material that has been tested. The competency test is conducted in an open and transparent manner, without any discrimination. Important things that must be fulfilled when a competency test is valid, effective, efficient, fair, flexible, and reliable. A person can take the competency test if he / she has an educational background and work experience that matches the competency test standards that he will follow. Competency tests can be in the form of written tests, practice, observation, and a combination of these tests.

\subsection{TOWS Theory Concepts}

According to Kertajaya, et al (Kertajaya, 2005) why use TOWS instead of SWOT as we usually hear, the explanation is very fundamental, because the analysis begins with a study of external factors by conducting a threat-opportunity analysis, then followed by a study of internal conditions. company in the form of strengthweakness. This kind of analysis sequence is based on the fact that in the 1990s 
environmental change and turbulence became increasingly important, far beyond changes in the internal environment, therefore we have to start from the outside, then start from the inside. In other words, we are using an outside-in, not inside-out approach.

When conducting a SWOT analysis, an organization may be trapped by placing too much pressure on internal factors and limiting the identification of threats and opportunities only to those that are in line with the company's capabilities. This does not mean that a company does not need to adjust the external environment to its internal conditions, this is the most important thing that companies must do. By examining all possible threats and opportunities before examining the company's weaknesses and strengths, we will tend to be better able to formulate and carry out the company's strategic steps. The TOWS analysis will provide a future paradigm so that the strategies created can also be used for the future.

TOWS analysis is one way to systematically identify various factors in order to formulate a company strategy. This analysis is based on logic by maximizing strengths and opportunities, but at the same time minimizing weaknesses and threats. The TOWS analysis considers the external environmental factors, opportunities and threats faced in the business world as well as the internal environment of strengths and weaknesses (Rangkuti, SWOT Balanced Scorecard, 2017). The TOWS matrix explains that there are four strategies we can develop:

a. SO Strategy, a strategy that utilizes strengths so that we can take advantage of existing opportunities.

b. WO strategy, a strategy that tries to minimize weaknesses or improve weaknesses in order to try to seize existing opportunities.

c. ST strategy, a strategy that uses strength to try to overcome or minimize the threats we face.

d. WT strategy, a strategy that tries to minimize or reduce weaknesses in order to prevent threats that must be faced.

\subsection{Interpretative Structure Model Theory (ISM)}

ISM is an analytical tool used in decision support tools that facilitates a comprehensive understanding of complex situations by linking and organizing ideas in a visual map (Darmawan, 2017). Interpretative structural modeling (ISM) is a method that is considered effective, this can be seen from all the elements that can be processed in a simple matrix, so that ISM is an ideal plan. ISM was first proposed in 1973 by Warfield. ISM is a methodology with the aim of identifying the relationship between items by defining the related problem or issue as well as an appropriate modeling technique in analyzing the relationship between one variable and another.

ISM has had phenomenal success when it comes to understanding situations and finding solutions to complex problems. ISM is proven to be effective in defining problems and attachments, evaluating impacts, and identifying relationships between policy sectors (Darmawan, 2017). ISM is able to identify structural relationships between specific variables of the system well. The main idea is to use the experience and knowledge of experts and scientists in breaking down complex elements into several sub-elements and building multilevel structural models. The ISM assessment is carried out in the groups selected for research in determining whether and how the relationships between variables are interrelated.

ISM begins with the identification of elements that are relevant to the problem or problem and extends to group problem solving techniques. A structural selfinteraction matrix (SSIM) was developed based on the comparison of the paired elements. There are procedures or stages in using the ISM method, these stages include (Firoz \& Rajesh, 2012)

a. Parameter identification.

The elements to be considered for identification of relationships were obtained through literature surveyors by conducting surveys.

b. Development of Structural Self Interaction Matrix (SSIM).

The development of the interpretive structural model begins with the construction of a structural self-interaction matrix, which shows the direction of contextual relationships among elements. In developing SSIM, the following four symbols have been used to indicate the direction of the relationship between two constraints $i$ and $j$.

\subsection{Research Approach}

This research is a quantitative research with a descriptive approach method. Quantitative research is one type of research with the characteristics of being carried out systematically, well-planned and structured. Quantitative research can also be interpreted as research based on positivism 
which is used to examine certain populations / samples with research instruments and quantitative data (Sugiyono, 2013). While the descriptive approach means that this research aims to describe / describe the object of research and the results of the research to the reader. This method also intends to provide an overview / description as it is without doing analysis or general conclusions first.

\subsection{Research Data Sources}

Researchers collect research data sources from primary data sources and secondary data sources. These two data sources are collected in order to provide various information about the data to be analyzed. Based on the research data source, the data collected was divided into 2 (two), namely:

a. Primary research data comes from data collected by the author from the first source or the place where the research object was carried out. Primary data in this study came from:

1) Fasharkan Jakarta

2) Disharkap Koarmada I

b. Secondary research data comes from data that has been previously collected by other researchers, agencies or other sources that have been tested / valid. Secondary data is obtained from literature, articles, journals and websites on the internet with regard to the research conducted.

\subsection{Research Subjects}

Research resource persons are people who understand about Fasharkan Jakarta. The resource persons used in this study were those who were directly involved in the research, namely, Kafasharkan Jakarta, Kadisharkap Koarmada, Kabagren / Fasharkan Jakarta Staff, Head of Jakarta Fasharkan Staff / Producer, Commander of KRI SRE and Kasubdis Plafform and Sewako.

\subsection{Data Collection Techniques}

Data collection is carried out to obtain the information needed in order to achieve the objectives of a study. In this research, data collection techniques were carried out through observation, interviews and documentation / literature study. Primary data through observation and interviews (in-depth interviews) are data collected and processed by the researcher from the subject or object of the study. Meanwhile, secondary data obtained from books, documentation and literature studies obtained indirectly from the subject or object of research.

\subsection{Data Analysis Technique}

Data analysis is intended to find elements or sections that contain smaller categories of research data. In this study, researchers collaborated with sources so that patterns were obtained that were in accordance with the object under study. Based on the existing problems, this research method uses the TOWS method. In the TOWS analysis, there are several stages including identifying external and internal factors, then compiling a matrix of external and internal factors and creating a questionnaire. From the results of the questionnaire, it can be concluded about the respondents' assessment of the existing indicators and compiled in a TOWS matrix. Then make an evaluation of external factors and internal factors by giving weight to strategic factors on a scale from 1 (bad) to 9 (good). Weighting of the group of factors and internal and external strategic factors through the pairwise comparison method. In developing alternative strategies, the TOWS matrix is used to help match the strengths and opportunities (SO strategy), strengths and threats (ST strategy), opportunities and weaknesses (WO strategy) and weaknesses and threats (WT strategy). After the strategy is made, the ISM method is used to prioritize these alternatives.

\subsection{Research Flowchart}


The research flowchart is as follows:

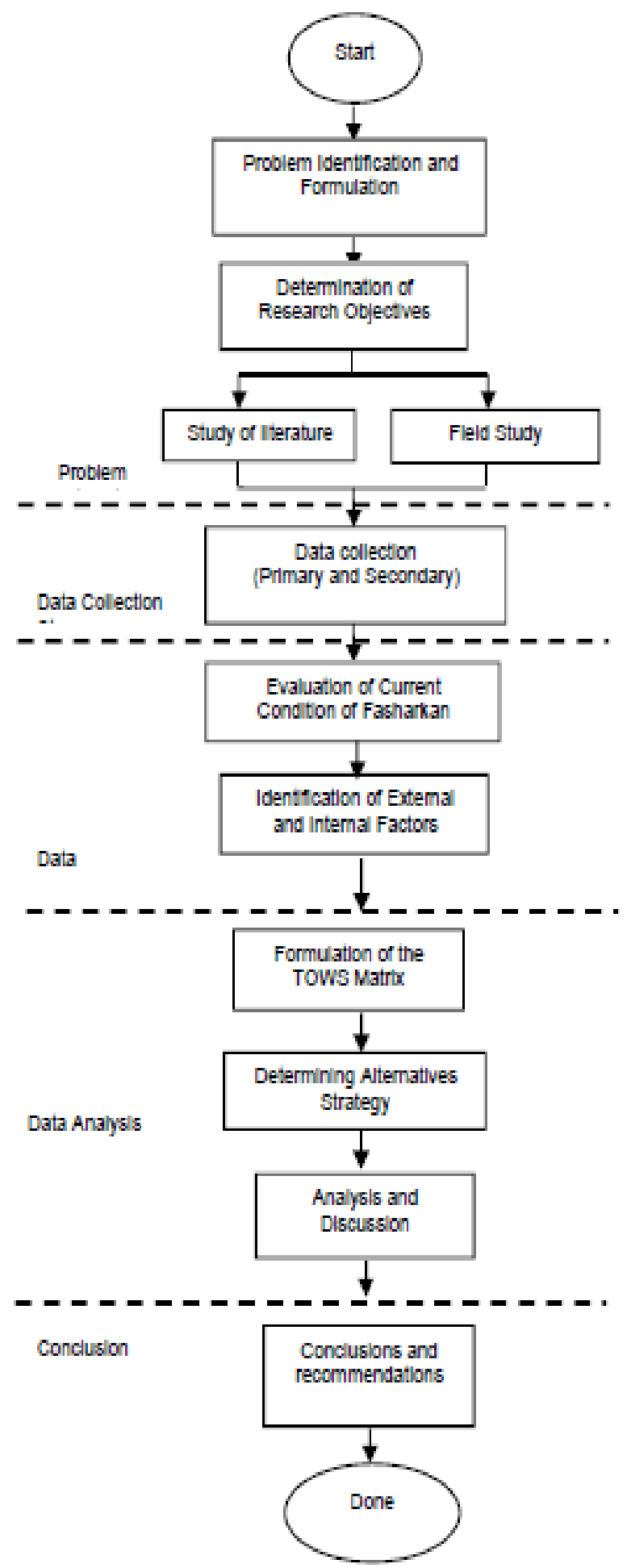

\subsection{TOWS Matrix}

From the identification of external and internal factors, the next step is to formulate strategic factors by combining external and internal factors to determine an alternative development strategy for Fasharkan Jakarta. The formulation and results of the strategy are obtained from the TOWS matrix. The TOWS matrix illustrates how external factors, namely opportunities and threats faced by the organization, are aligned with internal factors, namely the strengths and weaknesses of the organization. From this matrix, four alternative strategies for the development of Fasharkan Jakarta can be generated as shown in Figure 4.

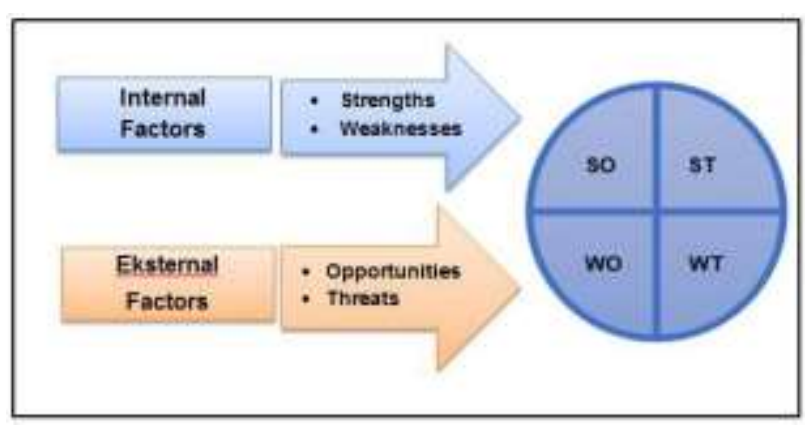

Figure 4. TOWS Matrix Analysis for Strategy Formulation

\section{Result and Discussion}

This strategy formulation section discusses the analysis of the results of weighting criteria and alternative strategies for the development of Fasharkan Jakarta using weighting from EFAS and IFAS SWOT. In weighting EFAS and IFAS using a questionnaire given to stakeholders in the development strategy of Fasharkan Jakarta.

\section{a. Weighting of External Factors (EFAS)}

After the opportunities and threats to external factors in the development of Fasaharkan Jakarta are known, then the EFAS weighting is carried out as in the following table:

Figure 3. Research Flowchart 
Table 1. Weighting of external factors opportunity

\begin{tabular}{|c|c|c|c|c|}
\hline External Factor Criteria & ssessment & $\begin{array}{c}\text { Weight } \\
\text { (B) }\end{array}$ & $\begin{array}{c}\text { Rating } \\
\text { (R) }\end{array}$ & $B \times R$ \\
\hline \multicolumn{5}{|l|}{ Opportunity (0) } \\
\hline $\begin{array}{l}\text { Government policy in } \\
\text { developing the shipping } \\
\text { industry as a driving } \\
\text { force for the national } \\
\text { economy }\end{array}$ & 8.00 & 0.07 & 3.50 & 0.24 \\
\hline $\begin{array}{lr}\text { Government } & \text { policy } \\
\text { regarding } & \text { the } \\
\text { procurement of new } \\
\text { KRI }\end{array}$ & 8.13 & 0.07 & 3.50 & 0.25 \\
\hline $\begin{array}{l}\text { The positive trend in } \\
\text { the growth of the } \\
\text { national ship fleet is a } \\
\text { lot of demand for ship } \\
\text { repair. }\end{array}$ & 7.13 & 0.06 & 2.75 & 0.17 \\
\hline $\begin{array}{l}\text { Economic growth } \\
\text { supports an increase in } \\
\text { the defense budget. }\end{array}$ & 7.38 & 0.06 & 2.88 & 0.18 \\
\hline $\begin{array}{l}\text { Having the availability } \\
\text { of young human } \\
\text { resources at each level }\end{array}$ & 7.50 & 0.06 & 3.25 & 0.21 \\
\hline $\begin{array}{l}\text { The demands of the } \\
\text { development of } \\
\text { shipping technology are } \\
\text { growing rapidly }\end{array}$ & 8.00 & 0.07 & 3.38 & 0.23 \\
\hline $\begin{array}{l}\text { The maritime industry } \\
\text { sector has } \\
\text { competitiveness at the } \\
\text { global level to realize } \\
\text { Indonesia as the world's } \\
\text { maritime axis. }\end{array}$ & 7.63 & 0.07 & 2.50 & 0.16 \\
\hline $\begin{array}{l}\text { The national defense } \\
\text { industry has gradually } \\
\text { increased } \\
\text { capabilities }\end{array}$ & 7.75 & 0.07 & 2.75 & 0.18 \\
\hline $\begin{array}{l}\text { The existence of } \\
\text { technology transfer fron } \\
\text { developed } / \text { friendly } \\
\text { countries }\end{array}$ & 7.25 & 0.06 & 3.25 & 0.20 \\
\hline $\begin{array}{c}\text { Number of } \\
\text { Opportunities }\end{array}$ & 68,75 & 0,59 & 27,75 & 1,83 \\
\hline
\end{tabular}

Table 2. Weighting of Threat External Factors

\begin{tabular}{|c|c|c|c|c|}
\hline Threat (T) & & & & \\
\hline $\begin{array}{l}\text { Bank interest rates } \\
\text { are still high }\end{array}$ & 7.63 & 0.07 & $\begin{array}{r}2.7 \\
5\end{array}$ & 0.18 \\
\hline $\begin{array}{l}\text { Defense budget is still below } \\
\text { standard ( } 2 \% \text { of GDP) }\end{array}$ & 8.13 & 0.07 & $\begin{array}{r}3.1 \\
3\end{array}$ & 0.22 \\
\hline $\begin{array}{l}\text { Requires a large budget } \\
\text { for software and hardware } \\
\text { needs }\end{array}$ & 8.00 & 0.07 & $\begin{array}{r}3.1 \\
3\end{array}$ & 0.22 \\
\hline $\begin{array}{l}\text { Lack of integrity between } \\
\text { similar industries in the form } \\
\text { of clusters in mutually } \\
\text { beneficial cooperation, } \\
\text { especially between BUMN } \\
\text { and the private sector in the } \\
\text { procurement of new vessels } \\
\text { and platforms }\end{array}$ & 8.00 & 0.07 & $\begin{array}{r}3.1 \\
3\end{array}$ & 0.22 \\
\hline $\begin{array}{l}\text { Still dependent on foreign } \\
\text { technology }\end{array}$ & 8.13 & 0.07 & $\begin{array}{r}3.2 \\
5\end{array}$ & 0.23 \\
\hline $\begin{array}{l}\text { Technology transfer is } \\
\text { still at } 50 \% \text { scale }\end{array}$ & 7.25 & 0.08 & $\begin{array}{r}3.0 \\
0\end{array}$ & 0.18 \\
\hline Number of Threat & $\begin{array}{l}47,1 \\
3\end{array}$ & 0,41 & \begin{tabular}{l|}
18,3 \\
6
\end{tabular} & 1,25 \\
\hline Total & $\begin{array}{l}115, \\
88\end{array}$ & 1,00 & \begin{tabular}{|l|}
46,1 \\
3
\end{tabular} & 3,08 \\
\hline
\end{tabular}




\section{b. Weighting of internal factors}

Table 3. Weighting of Internal Factors of Strength

After the strengths and weaknesses of the internal factors in the development of Fasharkan Jakarta are known, then the IFAS weighting is carried out as in the following table

\begin{tabular}{|c|c|c|c|c|}
\hline Internal Factor Criteria & $\begin{array}{l}\text { ssessm } \\
\text { ent }\end{array}$ & $\begin{array}{c}\text { Weigh } \\
t \\
(B)\end{array}$ & $\begin{array}{l}\text { Rati } \\
\text { ng } \\
\text { (R) }\end{array}$ & B x R \\
\hline \multicolumn{5}{|l|}{ Strengh $(0)$} \\
\hline $\begin{array}{l}\text { Able to carry out } \\
\text { docking up to } 700 \\
\text { tons }\end{array}$ & 7.50 & 0.06 & $\begin{array}{l}2.3 \\
8\end{array}$ & 0.14 \\
\hline $\begin{array}{c}\text { Workshop equipment } \\
\text { is sufficient }\end{array}$ & 7.63 & 0.06 & $\begin{array}{l}2.6 \\
3\end{array}$ & 0.16 \\
\hline $\begin{array}{l}\text { Having human } \\
\text { resources who have } \\
\text { skills in their fields }\end{array}$ & 8.00 & 0.06 & 2.50 & 0.16 \\
\hline $\begin{array}{c}\text { Human resources } \\
\text { have the ability to } \\
\text { interact with } \\
\text { computers well } \\
\end{array}$ & 7.88 & 0.06 & 3.00 & 0.19 \\
\hline $\begin{array}{l}\text { Technology transfer } \\
\text { cooperation opens } \\
\text { the way to mastering } \\
\text { technology }\end{array}$ & 7.63 & 0.06 & 3.00 & 0.18 \\
\hline $\begin{array}{c}\text { The managerial of } \\
\text { the organization is } \\
\text { quite solid }\end{array}$ & 7.50 & 0.06 & 2.63 & 0.16 \\
\hline $\begin{array}{l}\text { The budget comes } \\
\text { from APBN funds }\end{array}$ & 7.88 & 0.06 & 3.00 & 0.19 \\
\hline $\begin{array}{c}\text { Fasharkan's location is } \\
\text { very strategic } \\
\end{array}$ & 8.13 & 0.07 & 3.63 & 0.24 \\
\hline Number of Stren & $\begin{array}{l}62,6 \\
3\end{array}$ & 0,50 & $\begin{array}{l}22 \\
75\end{array}$ & 1,43 \\
\hline
\end{tabular}

\begin{tabular}{|c|c|c|c|c|}
\hline Weaknesses (W) & & & & \\
\hline $\begin{array}{c}\text { Workshop } \\
\text { equipment is old } \\
\text { or old }\end{array}$ & 7.63 & 0.06 & 3.38 & 0.21 \\
\hline $\begin{array}{l}\text { Docking capability is } \\
\text { limited to } 700 \text { tonnes }\end{array}$ & 7.63 & 0.06 & 3.13 & 0.19 \\
\hline $\begin{array}{l}\text { Lack of human } \\
\text { resources at } \\
\text { managerial and } \\
\text { operator levels }\end{array}$ & 7.75 & 0.06 & 3.13 & 0.19 \\
\hline $\begin{array}{c}\text { Huma Resourch does not } \\
\text { have a professional } \\
\text { certification }\end{array}$ & 7.63 & 0.06 & 2.88 & 0.18 \\
\hline $\begin{array}{c}\text { Not able to carry out KRI } \\
\text { repairs up to the depot } \\
\text { level }\end{array}$ & 7.88 & 0.06 & 3.25 & 0.21 \\
\hline $\begin{array}{l}\text { Much of the equipment } \\
\text { used is still manual }\end{array}$ & 7.88 & 0.06 & 3.25 & 0.21 \\
\hline $\begin{array}{l}\text { Do not have welding } \\
\text { technology with } \\
\text { aluminum and computer } \\
\text { systems }\end{array}$ & 7.63 & 0.06 & 2.88 & 0.18 \\
\hline $\begin{array}{l}\text { The budget from the } \\
\text { APBN is mostly for } \\
\text { personnel expenditure }\end{array}$ & 8.00 & 0.06 & 3.25 & 0.21 \\
\hline Number of Weaknesses & $\begin{array}{c}62,0 \\
0\end{array}$ & 0,50 & 25,13 & 1,57 \\
\hline Total & $\begin{array}{c}124, \\
63\end{array}$ & 1 & 47,88 & 3,00 \\
\hline
\end{tabular}

Table 4. Weighting External Factors Weaknesses

Strategic Factor Summary) processing, then determining the strategic quadrant position by entering into the weight score table by placing the difference between (S) and $\mathrm{W}$ values as the $X$ axis. As for the Opportunity value ( $O$ ) and Treats $(T$ ) are placed in the external column and the difference between $O$ and $T$ is a value on the $Y$ axis. In the weighting table for external and internal factors we can find that the value of the $X$ axis is -0.14 and the value of the $Y$ axis is 0.58 . From the difference in values in table 4:12 then we enter it in the strategy quadrant to determine the chosen strategy, so that we can analyze what strategy is right to use in problem solving. 
Tabel 5 . The Strategy Quadrant

\begin{tabular}{|l|c|l|c|}
\hline Internal (X) & Nilai & Eksternal (Y) & Nilai \\
\hline Strenght & 1,43 & Opportunity & 1,83 \\
Weaksness & 1,57 & Treats & 1,25 \\
\hline Selisih & $\mathbf{- 0 , 1 4}$ & & $\mathbf{0 , 5 8}$ \\
\hline
\end{tabular}

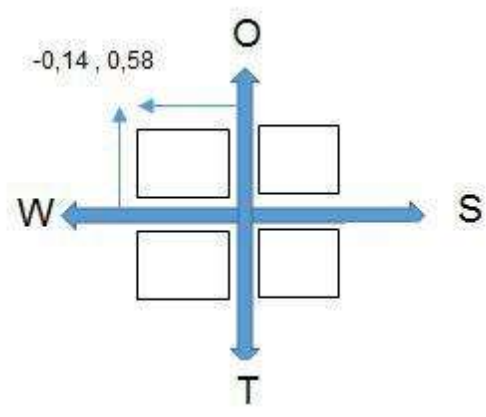

Figure 5. Quadrant Position

Seeing from Figure 5 the strategy quadrant above, that the position of the strategy lies in the WO quadrant, this shows that the WO strategy is a strategy used to solve problems, namely by minimizing weaknesses to take advantage of existing opportunities. The WO sub-strategies include:

a.Upgrade of equipment and workshop facilities in accordance with the latest technological advances.

b. Increase the capacity of the Slip Way to 700 tons.

c. Build a Flooting Dock with a capacity of 3000 tons

d. Increasing technology transfer cooperation with developed countries in the procurement of new ships.

e. Developing the capacity / education and human resource certification of Fasharkan Jakarta in line with the government's independence program.

f. Cooperating with the shipping service industry in accordance with government policies in developing the shipping industry as a driving force for the national economy.

g. Increase the budget sourced from the APBN in line with national economic growth to support the defense budget.

h. Carry out the recruitment of human resources more on the basic competencies of soldiers according to the profession in a strict and transparent manner. i. Fulfillment of the organizational structure, by increasing the number of human resources according to the DSP, so that they can carry out tasks optimally.

\section{c. Determination of Sub Strategy Formulation This sub-chapter will present the process of}

determining the priority of the sub-strategy for the development of Fasharkan Jakarta. The method used is Interpretative Structural Modeling (ISM). The first step is identifying the elements that need to be researched. In this study, these elements were obtained from the results of the strategy determination analysis in the TOWS analysis. Based on the results of the analysis, the selected strategy is the WO strategy as an alternative to the development strategy of Fasharkan Jakarta. The WO strategy consists of 9 (nine) sub strategies: 1) Upgrading equipment in accordance with the latest technological advances; 2 Increase the capacity of the Slip Way capacity to 700 tonnes .; 3) Build a Flooting Dock with a capacity of 3000 tons; 4) Increasing technology transfer cooperation with developed countries in the procurement of new vessels; 5) Developing the ability / education and certification of HR Fasharkan Jakarta in line with the government's independence program; 6) Cooperating with the shipping service industry in accordance with government policies in developing the shipping industry as a driving force for the national economy; 7) Increase the budget originating from the APBN in line with national economic growth to support the defense budget; 8) Carry out the recruitment of human resources more on the basic competencies of soldiers according to the profession in a strict and transparent manner; 9) Fulfillment of the organizational structure, by increasing the number of human resources according to the DSP, so that they can carry out their duties optimally. 
Table 6 . Result of Determining Sub Strategy

\begin{tabular}{|c|c|}
\hline Code & Sub Strategi WO \\
\hline WO1 & $\begin{array}{l}\text { Upgrade equipment in accordance } \\
\text { with the } \\
\text { latest technological advances; }\end{array}$ \\
\hline WO2 & $\begin{array}{l}\text {. Increase the capacity of the Slip Way } \\
\text { to } 700 \\
\text { tons }\end{array}$ \\
\hline WO3 & $\begin{array}{l}\text { Building a Flooting Dock with a } \\
\text { capacity of } \\
3000 \text { tons; }\end{array}$ \\
\hline WO4 & $\begin{array}{l}\text { Increase technology transfer } \\
\text { cooperation with } \\
\text { developed countries in the procurement } \\
\text { of new } \\
\text { vessels; }\end{array}$ \\
\hline WO5 & $\begin{array}{l}\text { Developing the capacity / education } \\
\text { and } \\
\text { human resource certification of } \\
\text { Fasharkan } \\
\text { Jakarta in line with the } \\
\text { government's } \\
\text { independence program; }\end{array}$ \\
\hline WO6 & $\begin{array}{l}\text { Cooperating with the shipping service } \\
\text { industry } \\
\text { in accordance with government } \\
\text { policies in } \\
\text { developing the shipping industry as a } \\
\text { driving } \\
\text { force for the national economy; }\end{array}$ \\
\hline WO7 & $\begin{array}{l}\text { Increase the budget sourced from the } \\
\text { APBN in } \\
\text { line with national economic growth to } \\
\text { support } \\
\text { the defense budget; }\end{array}$ \\
\hline WO8 & $\begin{array}{l}\text { Carry out the recruitment of human } \\
\text { resources } \\
\text { more on the basic competence of } \\
\text { soldiers } \\
\text { according to the profession in a } \\
\text { strict and } \\
\text { transparent manner; }\end{array}$ \\
\hline W09 & $\begin{array}{l}\text { Fulfillment of the organizational } \\
\text { structure, by } \\
\text { increasing the number of human } \\
\text { resources } \\
\text { according to the DSP, so that they can } \\
\text { carry } \\
\text { out tasks optimally }\end{array}$ \\
\hline
\end{tabular}

In the SSIM matrix, it represents the elements of the Expert's perception of the intended goal elements. The four symbols used to represent the type of relationship that exist between the two elements of the two systems under consideration are:

1. $\mathrm{V}$ : The relationship of Ei affects Ej, not vice versa;

2. A: The relationship of Ej affects $\mathrm{Ei}$, not vice versa;

3. X: The relationship between Ei and $\mathrm{Ej}$ affects each other;

4. O: Indicates that Ei and Ej are not related.

Based on the data and calculations made from the results of the assessment of the ISM questionnaire, the results are as in table 7 .

Table 7. ISM Assessment Results

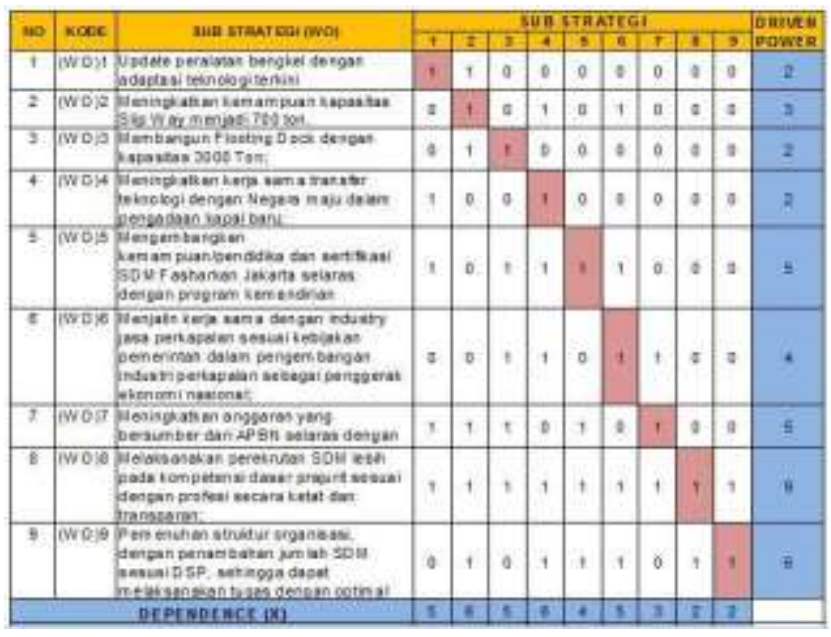

Furthermore, the calculation of Dependent $(x)$ and Driven Power $(y)$ is described in the Micmac Diagram as follows:

Table 8. Dependent $(X)$ and Driven Power (Y) coordinate results

\begin{tabular}{|c|c|c|}
\hline ALTERNATIF & $\begin{array}{c}\text { DEPENDEN } \\
T\end{array}$ & DRIVEN \\
\hline STRATEGI & $(X)$ & $\begin{array}{c}\text { POWER( } \\
\text { Y) }\end{array}$ \\
\hline (WO) 1 & 5 & 2 \\
\hline (WO) 2 & 6 & 3 \\
\hline (WO) 3 & 5 & 2 \\
\hline (WO) 4 & 6 & 2 \\
\hline (WO) 5 & 4 & 5 \\
\hline (WO) 6 & 5 & 4 \\
\hline (WO) 7 & 3 & 5 \\
\hline (WO) 8 & 2 & 9 \\
\hline (WO) 9 & 2 & 6 \\
\hline
\end{tabular}


From these coordinates can be drawn on the Micmac analysis diagram. Based on the MICMAC Analysis Diagram image above, it can be seen that:

a. Sector I (Autonomous Variable) has no variables. This sub strategy is an element that has little dependence on other elements.

b. Sector II (Dependent Variable) has five substrategy elements, namely (WO1), (WO2), (WO3), (WO4) and (WO6). The sub strategy on this variable has a high dependence on other elements.

c. Sector III (linkage variable) has no variables... d. Sector IV (Independent Variable) has four elements of strategic variables, namely (WO5), (WO7), (WO8) and (WO9).

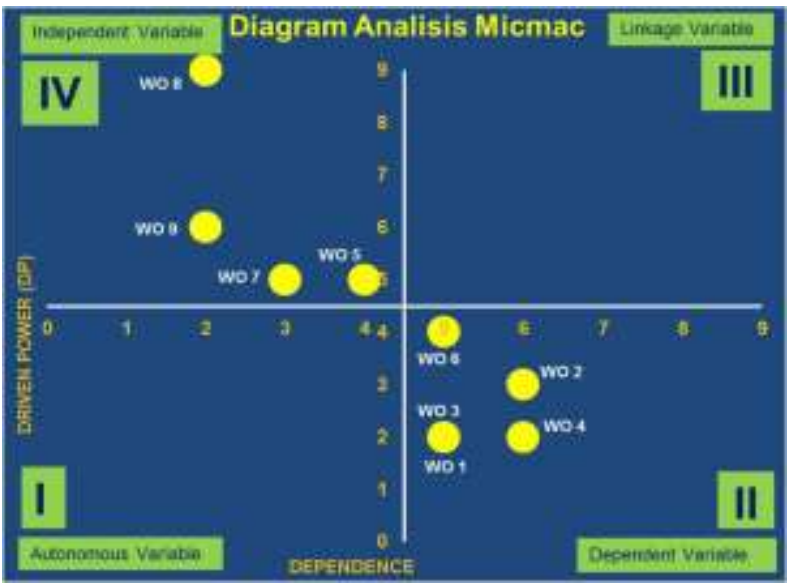

Figure 6. MICMAC Analysis Diagram

In Figure 6, the MICMAC analysis diagram above is arranged based on the driver power and dependent coordinate points for each strategy sub-element. Furthermore, the classification of sub-elements of the Jakarta Fasharkan development strategy is as follows:

Tabel 9. Sub-element Classification

\begin{tabular}{|c|c|c|}
\hline Vanabel & Sub Strategi & Jumiah \\
\hline$\underset{(\rightarrow)}{\substack{1 \\
(\rightarrow)}}$ & - & \\
\hline \multirow{5}{*}{$\begin{array}{c}\text { Degendent } \\
(-)(+)\end{array}$} & $\begin{array}{l}\text { Upprade peralatan segual dengan kemajuan teknoloo } \\
\text { terkini work }\end{array}$ & \multirow{5}{*}{5} \\
\hline & $\begin{array}{l}\text { Meningiratian kemampuan kapastas 5lip Way mengad } \\
700 \text { ton (WO2). }\end{array}$ & \\
\hline & $\begin{array}{l}\text { Membargun Floc6ng Dock dongan kapasitas } 3000 \text { ton } \\
\left(w_{03}\right)\end{array}$ & \\
\hline & 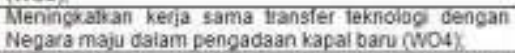 & \\
\hline & 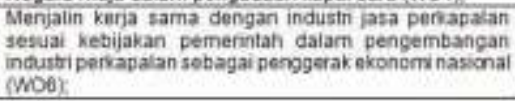 & \\
\hline $\begin{array}{l}111 \\
\text { Linkage } \\
(+)(+)\end{array}$ & - & \\
\hline \multirow{4}{*}{$\begin{array}{l}\text { IV } \\
\text { Independent } \\
(+)(-)\end{array}$} & $\begin{array}{l}\text { Mengembanokan kemgmpuan)endckan dan gertifikasi } \\
\text { SOM Fasharkan Jakarta selaras dengan program } \\
\text { kemandirian pemerintah (wO5) }\end{array}$ & \multirow{3}{*}{4} \\
\hline & $\begin{array}{l}\text { Meningkatian anggaran yang bersumber dari APEN } \\
\text { selaras dengan pertumbuhan ekonami nasional untuk } \\
\text { mendukung anggaran pertahanan (W07) }\end{array}$ & \\
\hline & 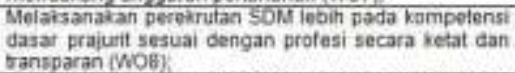 & \\
\hline & $\begin{array}{l}\text { Pemenuhan atrukur organisasi, dengan penambahan } \\
\text { Jumlah SDMM sesuaiDSP, sehingea dapatmelaksanakan } \\
\text { ugas dengan optimal (Wog) }\end{array}$ & \\
\hline
\end{tabular}

From table 9 it can be seen that in sector II (Dependent Variable) there are five elements of the sub strategy, namely upgrading equipment according to the latest technological advances (WO1), increasing the capacity of the Slip Way capacity to 700 tons (WO2), building a Flooting Dock with a capacity of 3000 tons (WO3), increasing technology transfer cooperation with developed countries in procuring new ships (WO4) and establishing cooperation with the shipping service industry in accordance with government policies in developing the shipping industry as a driver of the national economy (WO6). This sub strategy has a high dependence on other elements. This shows that these elements have relatively small driving power and are highly dependent on other elements as triggers in the development of Fasharkan Jakarta.

Then, sector IV (Independent variable) has four variables, namely developing the ability / education and certification of Human Resources of Fasharkan Jakarta in line with the government independence program (WO5), Increasing the budget sourced from the APBN in line with national economic growth to support the defense budget (WO7), Implementing $\mathrm{HR}$ recruitment is more on the basic competence of soldiers according to the profession in a strict and transparent manner (WO8) and Fulfillment of the organizational structure, by increasing the number of human resources according to the DSP, so that they can carry out their duties optimally (WO9). The sub-strategies (WO5), (WO7), (WO8) and (WO9) have a very strong influence and are a key variable for the success of the Jakarta Fasharkan development program. Variable (WO8), namely Carrying out more HR recruitment on the basic competence of soldiers according to the profession in a strict and transparent manner and variable (WO9) Fulfillment of the organizational structure by increasing the number of human resources according to the DSP, so that they can carry out tasks optimally, have the greatest motivation because they have drivers the highest power among other variables. Then the second highest ranking of driving force consists of 2 strategic variables, namely the (WO7) and (WO5) variables, namely increasing the budget sourced from the APBN in line with national economic growth to support the defense budget and developing the ability / education and certification of Fasharkan Jakarta's human resources in line with the program. the independence of the government so that in an integrated manner 
it can be a driving factor in the successful development of Fasharkan Jakarta.

Based on the results of Micmac analysis (Figure 7), there are 5 (five) levels of strategy structure which can be described as follows:

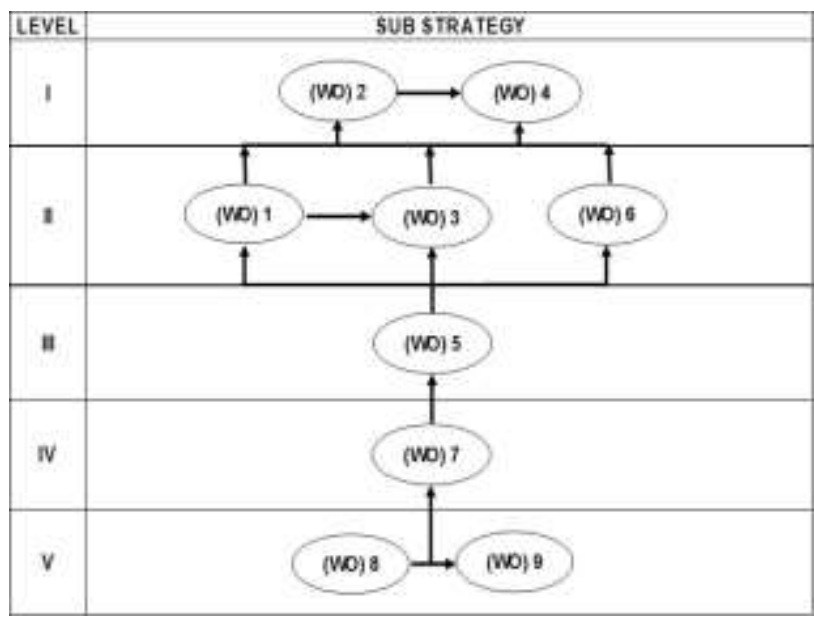

Figure 7 . Hierarchical Structure of Modeling

\section{Development of Fasharkan Jakarta}

Based on the results of the classification of elements in the WO strategy, there are five levels of hierarchical structure as shown above. In this hierarchical structure it can be seen that: a. At level $\mathrm{V}$ there are two sub strategies, namely (WO8) Carrying out more HR recruitment on the basic competence of soldiers according to the profession strictly and (WO9) fulfilling the organizational structure, by increasing the number of human resources according to the DSP, so that they can carry out tasks optimally.

b. At level IV, there is one sub strategy (WO7). Increase the budget sourced from the APBN in line with national economic growth to support the defense budget.

c. At level III, it consists of one sub strategy (WO5) to develop the ability / education and certification of HR Fasharkan Jakarta in line with the government's independence program.

d. At level II it consists of three sub strategies, namely (WO1) upgrading equipment according to the latest technological advances, (WO3) building a Flooting Dock with a capacity of 3000 tons and (WO6) establishing cooperation with the shipping service industry according to government policies in developing the shipping industry as a driving force national economy. e. At level I there are two sub strategies (WO2), namely increasing the capacity of the Slip Way to 700 tons and the strategy (WO4) of increasing technology transfer cooperation with developed countries in procuring new vessels.

Based on the hierarchical structure of modeling, the development of Fasharkan Jakarta starts with the implementation of HR recruitment, which is more strictly and transparently based on the basic competencies of soldiers according to the profession, so that the fulfillment of the organizational structure and increasing the number of human resources according to DSP (WO8, WO9). After the fulfillment of the number of human resources at Fasharkan Jakarta, the next strategy is to increase the budget sourced from the State Budget which is in line with national economic growth to support the defense budget (WO7). Furthermore, there will be an increase in HR professionalism by developing educational capabilities and HR certification that are in line with the national independence program (WO5). After the fulfillment of professional human resources, an increase in the defense budget and an increase in the capacity of human resources expertise, physical development will be carried out by upgrading workshop equipment according to the latest technology (WO1), building a floating dock with a capacity of 3000 tons (WO6) and establishing cooperation with the shipping service industry. The last stage in the development strategy of Fasharkan Jakarta is to increase the slipway capability to 700 tons (WO4) and carry out technology transfer cooperation with developed countries in the construction of new ships.

\section{d. Roadmap for Jakarta's Fasharkan Development Strategy. \\ The following is a roadmap of the} results of the Jakarta Fasharkan development strategy.

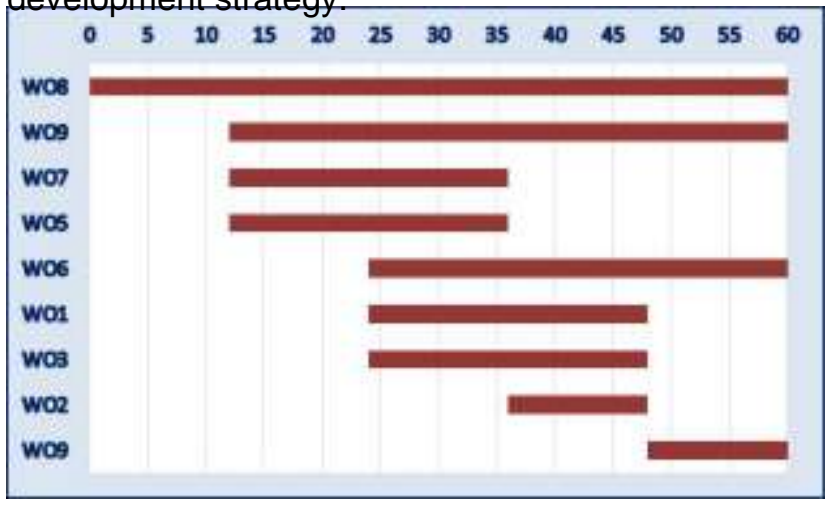

Figure 8. Graph Plan Implementation phase Figure 8 describes the implementation plan 
for the Jakarta Fasharkan development strategy in a strategic plan (Renstra) which spells out a period of five years (60 months). Strict and transparent recruitment of HR based on basic competence of soldiers according to profession (WO8) is carried out within a period of five years (60 months). Then the sub strategy of Fulfilling the organizational structure, by increasing the number of human resources according to the DSP, so that it can carry out tasks optimally (WO9) is carried out within 48 months.

Fulfillment of the organizational structure, by increasing the number of human resources according to the DSP, so that they can carry out tasks optimally (WO9) within 24 months. Developing the ability / education and certification of HR Fasharkan Jakarta in line with the government self-reliance program (WO5) implemented for 24 months; Collaborating with the shipping service industry in accordance with government policies in developing the shipping industry as a driver of the national economy (WO6) is carried out in 36 months. Equipment upgrades in accordance with the latest technological advances (WO1) and Building a Flooting Dock with a capacity of 3000 tons (WO3) were carried out in 24 months. Furthermore, the sub-strategy of increasing the capacity of the Slip Way capacity to 700 tons (WO2) is carried out within 12 months and increasing technology transfer cooperation with developed countries in the procurement of new vessels (WO4) is carried out within 12 months.

\section{e. Implementation Stages}

The plan for the development stages of Fasharkan Jakarta is generally implemented in one strategic plan (renstra) which is divided into five-year programs. The first and second years constitute the first phase of developing the basic foundation by recruiting according to the competence and fulfillment of existing human resources in Fasharkan according to current DSP needs to produce professional Fasharkan personnel. In this phase there will also be an increase in the budget sourced from the APBN in line with national economic growth to support the defense budget and carry out the development of the capacity / education and certification of Fasharkan Jakarta's human resources in mastery of marine technology in line with the government's independence program.

The second phase consists of the third and fourth years which are the restructuring stages of the development of Fasharkan Jakarta. In this phase, cooperation with the shipping / maritime service industry will be initiated according to government policy in developing the shipping industry as a driving force for the national economy, upgrading all old workshop equipment, increasing slipway capacity to 700 tons and building a floating dock with a capacity of 3000 tons. At this stage, efforts were also made to improve and develop the capabilities and strengths of Fasharkan Jakarta.

The third phase, namely the fifth year, is the stage of reaping the results of several previous stages. This result is in the form of an increase in the ability of Fasharkan Jakarta, however, at this stage it is also necessary to carry out an evaluation study of several sub-programs that have been implemented and the impact of the implementation of the program. The purpose of this process is a roadmap or map of the plan in the form of a five-year Strategic Plan document containing an explanation of the organizational goals to be achieved and future estimates.

\section{CONCLUSION}

In this study, to obtain the expected results, several stages were carried out, starting from the identification of problems, formulating strategies to determining strategic priorities and also conducting sub-strategy mapping. Based on the analysis and discussion, the conclusions of this study can be obtained, including the following:

1) From the results of the identification of the TOWS analysis and the results of the FGD with the exspert Fasharkan Jakarta has an External Threat Factor (Treath), namely threats in the South China Sea, piracy piracy in the Malacca Strait, requiring a large budget for software and hardware needs, lack of integrity between similar industries in the form of clusters in mutually beneficial cooperation, especially between BUMN and the private sector, still dependent on foreign technology and technology transfer is still on a $50 \%$ scale. The TOWS analysis also shows that Fasharkan Jakarta has opportunities (Opportunities), namely government policies in developing the shipping industry as a driver of the national economy, government policies regarding the procurement of new $\mathrm{KRI}$ programs for domestic production, positive trends in the growth of national vessels, many requests for ship repair, national economic growth support an increase in the defense budget, have the availability of young human resources at every stratum, the demand for the development of shipping technology is growing rapidly, the maritime industry sector has competitiveness at the global level to 
realize Indonesia as the world's maritime axis, the shipbuilding industry has gradually increased its capabilities, and The existence of technology transfer from developed / friendly countries.

2) In identifying the TOWS analysis and the results of the Fasharkan Jakarta expert's FGD in the form of Internal Factors in the form of weaknesses (Weaknesses) of Fasharkan Jakarta, namely many workshop equipment that are elderly, have not been able to carry out docking of all types of KRI, lack of human resources at managerial and technician levels, HR has not professionally certified, has not been able to carry out KRI repairs to the depot level, many of the workshop equipment used are still manual, do not have computer-based welding technology and the existing budget is mostly for personnel expenses. Then the Strength factor (Strength) from Fasharkan Jakarta is being able to carry out docking up to 600 tons, have human resources who have skills according to their fields, have human resources with good computing interaction skills, technology transfer cooperation opens the way to mastery of technology, organizational managerial is quite solid, budget is sourced from the state budget and the location of Fasharkan Jakarta is very strategic.

3. In the formulation of the development strategy of Fasharkan Jakarta, based on the TOWS analysis, 4 (four) alternative strategies were obtained, namely the SO Strategy, the ST Strategy, the WO Strategy and the WT Strategy. The SO strategy consists of 8 (eight) strategy steps, the ST strategy consists of 4 (four) strategic steps, the WO strategy consists of 9 (nine) strategic steps and the WT strategy consists of 4 (four) strategic steps. From the weighting results of External factors and Internal Factors EFAS / IFAS, it is obtained a calculation which shows that the best strategy is the WO strategy from the calculation of the strategy quadrant, so that the WO Strategy which consists of 9 (nine) sub strategies becomes the first alternative in the development strategy of Fasharkan Jakarta.

4. From the results of the EFAS / IFAS matrix in the TOWS analysis, a WO strategy consisting of 9 (nine) sub-strategies is obtained, followed by processing with the ISM method for determining the priority scale of the WO sub-strategy in the development of Fasharkan Jakarta.

a) From the results of this study, it is found that the classification of elements in the WO strategy is obtained 5 (five) levels of hierarchical structure. At level $\mathrm{V}$ consists of sub strategies (WO8) and (WO9). At level IV consists of sub strategies (WO7) and at level III consists of sub strategies (WO5). Furthermore, at level II it consists of 3 sub strategies, namely sub strategies (WO1), (WO3) and (WO6) and at level I consists of sub strategies (WO2) and (WO4).

b) The elements of the Jakarta Fasharkan development sub strategy can be classified into 4 (four) sectors. The autonomous variable (sector I) has no variables. Sector II (Dependent Variable) consists of 5 sub strategies, namely (WO3), (WO2), (WO3) and (WO4). Sector III (variable linkage) also has no variables. Then in sector IV (Independent variable) has four sub strategy variables, namely (WO5), (WO7), (WO8) and sub strategy (WO9).

c) The road map for the development of Fasharkan Jakarta carries out the recruitment of more human resources on the basic competence of soldiers according to the profession in a strict and transparent manner (WO8) implemented starting in 2021 for 60 months. Then the sub strategy Fulfillment of the organizational structure, by increasing the number of human resources according to the DSP, so that they can carry out tasks optimally. (WO9) will be implemented starting in 2022 within 48 months. Increase budget sourced from the APBN in line with national economic growth to support the defense budget (WO7) implemented starting in 2022 within 24 months. Developing the ability / education and human resource certification of Fasharkan Jakarta in line with the government independence program (WO5) implemented starting in 2022 for 24 months, Collaborating with the shipping service industry in accordance with government policies in developing the shipping industry as a driver of the national economy (WO6) implemented starting in 2022 for 36 months. Equipment upgrades in accordance with the latest technological advances (WO1) will be carried out starting in 2023 for 24 months, building a Floating Dock with a capacity of 3000 tons (WO3) is carried out starting in 2023 within 24 months. Increase the capacity of the Slip Way to 700 tons. (WO2) will be implemented starting in 2024 within 12 months and increasing technology transfer cooperation with developed countries in the procurement of new ships (WO4) will be implemented in 2024 for 24 months.

\section{ACKNOWLEDGMENT}

This research has been Supported by Indonesia Naval Technology College (STTAL), Indonesian Navy and Ministry of Defense of the Repulic Indonesia. 


\section{REFERENCE}

Ahmadi. (2017). Applied of ImpressedCurrent Cathodic Protection Design for Fuel Pipeline. Iranian Journal of Materials Science and Engineering, 41-52.

Asmoro, R. D. (2018). Submarine Operations Degree Strategy in Support of Three Fleet Commandos to Strengthen the Archipelago's

Maritime Defense Strategy. surabaya: Naval Technology College (Thesis).

Bandono, A. (2017). The Use Of Value Clarification Technique-Based- Picture Story Media As An Alternative Media To Value Education In Primary School. Journal of Arts Research and Education 17 (1), 68-67.

Darmawan, D. P. (2017). Structured Decision

Making With Interpretative Structural

Modeling. Yogyakarta: Publisher Elmatera.

Firoz, N., \& Rajesh, R. (2012). Relationship among

Supplier Selection Criteria using Interpretative Structural Modeling for Manufacturing Organization in Kerala. International Journal of Engineering Science Invention, $3(8), 60-70$.

Hunger, J. D., \& Wheelen, T. L. (2010). Essentials Of Strategic Management 5th edition. United States of America: Prentice Hall.

Hussain, M. (2011). Modeling the Enablers and Alternatives for Sustainable Supply Chain Management. Montreal: Concordia University.

I Made Jiwa Astika1, K. G. (2018). Measurement of Indonesian Naval Base Development in a Border Area: A Case Study. International Journal of Applied Engineering Research ISSN 0973-4562 Volume 13, Number 3, 1560-1566.

Istiqomah, A. (2017). Human Resources development strategies as an effort to improve the performance of village officials using a SWOT analysis. Journal of the State University of Malang, 1-9.
J. David Hunger, T. L. (2003). Strategic Management. Yogyakarta: ANDI.

Kasal. (2013). Regulation of the Chief of Naval Staff Number KEP / 1771 / XII / 2013 concerning Technical Manual for Standardization of

Indonesian Navy Bases.

Headquarters.

Kasal, K. (2018). Head of Kasal Number Kep $/ 1111$

/ V V / 2018 concerning the Doctrine of the Indonesian Navy Jalesveva Jayamahe. Jakarta: Headquarters.

Kertajaya, H. (2005). Markplus on Strategy 12 years of Markplus \& Go's journey to build a marketing strategy. Jakarta: PT Gramedia Pustaka Utama.

Khoiroh, S. M. (2016). Formulation of a Policy Strategy Roadmap for Strengthening the Regional Innovation System (SIDa) in the

Maritime Industry Sector for Small-scale Ship IKM in Lamongan. Surabaya: Faculty of Industrial Technology, Sepuluh Nopember Institute of Technology.

Lumaksono, H. (2014). Implementation Of SWOT-FAHP Method To Determine The Best Strategy On Development Of Traditional Shipyard In Sumenep. Academic Research International Vol. 5 (5) September 2014, 56-67.

Nurcahya Dwi Asmoro, B. S. (2018). Formulation of Maritime Industry Mastery Strategies to Strengthen National Defense. Journal of Industrial Systems Optimization, 162-170.

Oreski1, D. (2012). Strategy Development By Using

SWOT - AHP. TEM Journal, 283-291.

Panackal, N., \& Singh, A. (2016). Using Interpretative Structural Modeling to Determine the Relation between Youth and Sustainable Rural Development. Journal of Management and Research, 4 (1), 58-64.

Presidential Decree No. 16. (2017). Indonesia is the World Maritime Axis. 
Jakarta: Coordinating Ministry for Maritime Affairs.

Puskom. (2015). 2015-2035 National Industrial

Development Master Plan. Jakarta: Ministry of Industry.

Operation. Journal of Defense Management, 18.

Rangkuti, F. (2018). SWOT analysis. Jakarta: PT Gramedia Pustaka Utama.

Rizal, O. (2015). Strategic feasibility of relocating the TNI AL base in supporting the main tasks of elemental operations. Surabaya: STTAL Thesis.

Singh2, N. P. (2015). Using Interpretive Structural Modeling to Determine the Relation between Youth and. IBMRD's Journal of Management and Research, 58-74.

Suastika, W. A. (2017). Analisys Development

Of Green Ship-Recycling yard.

National

Oceanic Journal, 33-34.

Suharjo, B. (2013). Applied statistics Dissertation example Application with SPSS. Yogyakarta: Graha Science.

Suharyo, O. S. (2017). Establishing the location of naval base using fuzzy MCDM and covering technique methods: A case study. International Journal of Operations and Quantitative Management IJOQM Vol 23 Issue 1, 
